WARSZTATY Z GEOGRAFII TURYZMU

ISBN 978-83-7969-138-8 $\quad$ s. 207-223

http://dx.doi.org/10.18778/7969-138-8.14

Justyna MOKRAS-GRABOWSKA

Uniwersytet Łódzki

\title{
KOMERCJALIZACJA KULTURY LUDOWEJ POD WPEYWEM TURYSTYKI. WYBRANE PRZYKŁADY W POLSCE ${ }^{1}$
}

\section{Wprowadzenie}

Zasoby kultury ludowej są jednym z elementów przestrzeni turystycznej. $\mathrm{W}$ wielu regionach stanowią o ich atrakcyjności i konkurencyjności, z czym związane jest ich uproduktowienie. Współczesne środowisko wiejskie, przechodząc transformacje społeczno-gospodarcze, zmienia swoje pierwotne wartości kulturowe, które stają się dziś jedynie „refleksją nad przeszłością” (PRZYBYŚ 2008). Dawna kultura ludowa przyjmuje nową, skomercjalizowaną formę i coraz częściej służy jedynie jako „zdobnik” i element oferty turystycznej regionów. Zasoby kultury ludowej są na potrzeby ruchu turystycznego "przefiltrowane” i dostosowane do gustów klientów. W wyniku tych działań dochodzi do procesów akulturacji, niszczenia struktur społecznych i relacji w społecznościach lokalnych (ZARĘBA 2006). Wykorzystanie zasobów kultury ludowej w turystyce prowadzi jednak również do zachowania i ochrony dziedzictwa kulturowego - $\mathrm{w}$ wielu regionach tradycje bez zainteresowania „z zewnątrz” uległyby zapomnieniu (PRZYBYŚ 2008).

Opracowanie powstało $\mathrm{w}$ oparciu o rozprawę doktorską autorki, której głównym celem było określenie charakteru wykorzystania zasobów kultury

\footnotetext{
${ }^{1}$ Opracowanie prezentuje główne wyniki badań rozprawy doktorskiej autorki.
} 
ludowej w Polsce oraz stopnia ich komercjalizacji, poprzez zastosowanie uniwersalnej koncepcji modelu badań komercjalizacji kultury ludowej pod wpływem turystyki. Badania przeprowadzono w trzech regionach: włodawskim, podhalańskim i kartuskim.

\section{Wokół komercjalizacji kultury ludowej - próba usystematyzowania terminologii}

Komercjalizacja kultury ludowej (folkloryzm) rozumiana jest jako jej funkcjonowanie na zasadach rynkowych, handlowych i obliczonych na zysk, co na ogół wiąże się z instrumentalnym traktowaniem wartości wyższych, upraszczaniem ich form, produkowaniem masowych dzieł sztuki dla mniej wymagającej pop-kultury (OLECHNICKI, ZAŁĘCKI 1999). W wyniku takich działań elementy tej kultury wyzbywają się najczęściej swojej autentyczności. Częstym zjawiskiem w tym przypadku jest powstawanie wyrobów określanych jako tandetne i kiczowate. Pod wpływem oddziaływania turystyki kultura ludowa komercjalizuje się zawsze, może jednak mieć formę skomercjalizowaną autentyczną albo nieautentyczną.

Według Wielkiego słownika woyrazótw obcych (2003), autentyczny to zgodny z rzeczywistością, niebędący kopią i przeróbką, zachowujący się zgodnie ze swoimi odczuciami i przekonaniami. Jest przeciwieństwem naśladownictwa lub tego, co jest efektem przystosowania się do otoczenia. Zdaniem autorki autentyczność kultury ludowej może być zachowana głównie za sprawą zrównoważonych form turystyki, które oznaczają indywidualny ruch turystyczny i mniejszą presję na środowisko kulturowe, a w ostateczności harmonię pomiędzy środowiskiem przyrodniczym, społecznym i kulturowym.

Formą turystyki wykorzystującą zasoby kultury ludowej jest turystyka folklorystyczna (etnograficzna). Mimo że taka forma turystyki nie jest nowa, stosunkowo niedawno jest określana przytoczonym terminem (KOWALCZYK 2008). Walorami wykorzystywanymi przez turystykę folklorystyczną są m.in. imprezy folklorystyczne, muzea etnograficzne (w tym głównie skanseny), warsztaty twórców ludowych oraz zachowane święta, obrzędy i zwyczaje.

W literaturze przedmiotu często można się spotkać z różnorodnymi określeniami odnoszącymi się do zjawiska folkloryzmu. Początki koncepcji głoszącej komercjalizację kultury poprzez turystykę sięgają lat 60. XX w., 
kiedy amerykański historyk kultury Daniel Boorstin badał zjawisko tzw. pseudowydarzeń (ĆWIKLIŃSKA 2009). Twierdził on, że w obecnym świecie turyści nie doświadczają rzeczywistości, lecz są świadkami sztucznie wykreowanej przestrzeni, w której turysta funkcjonuje komfortowo, lecz bez autentycznego kontaktu z rzeczywistością (efekt tzw. bańki środowiskowej). Atrakcje turystyczne są $\mathrm{z}$ reguły odpowiednio zmienione na potrzeby ruchu turystycznego - „przefiltrowane” i dostosowane do gustów klientów. Wpływ turystyki na środowisko społeczno-kulturowe dotyczy np. zwyczajów, tradycji, wierzeń, wartości, więzi rodzinnych i stosunków społecznych (ZARĘBA 2006). Najbardziej drastycznie zjawisko to przebiega w krajach rozwijających się lub w krajach Trzeciego Świata (tzw. forma kolonializmu). Do kolonializmu kulturowego nawiązuje m.in. socjologiczna teoria konfliktu, w której turystyka jest widziana jako przejaw imperializmu (konflikt pomiędzy gośćmi i gospodarzami w obszarze recepcji turystycznej) i wywołuje zjawisko tzw. gościnności komercyjnej (kupieckiej) (PRZECŁAWSKI 1996). W takim przypadku turyści i mieszkańcy odgrywają pewne "role” w przestrzeni spotkań, o której traktuje teoria etnometodologii (ról społecznych) E. Goffmana. Proponowane przez mieszkańców atrakcje, dobra i usługi nie mają zatem charakteru autentycznego. $W$ wyniku omówionych zjawisk powstaje tzw. przestrzeń gościnności, będąca efektem celowych, wyuczonych i komercyjnych działań dążących do zaspokojenia potrzeb turystów (WŁODARCZYK 2009). Jest ona niejako przeciwieństwem tzw. przestrzeni gościnnej sensu stricto, będącej wynikiem naturalnych, niekomercyjnych postaw mieszkańców wobec przyjeżdżających turystów.

Następuje proces „produkowania lokalnej kultury” (tzw. uproduktowienie) na użytek turystów, co ma związek z przystosowaniem jej elementów do ich wyobrażeń. Na potrzeby turystów tworzone są nowe obrzędy i zwyczaje, które nigdy w danym regionie nie były kultywowane. Prowadzi to do powstania kultury komercyjnej, uproduktowionej (tzw. fake folklore). Standaryzacja turystyczna prowadzi z kolei do tzw.makdonaldyzacji i makdisneyizacji - unifikacji, zaniku autentyczności i popierania "przyjemnej rozrywki”, zwanej także karnawalizacją (GEISE 2008). Niesie ona ze sobą znaczące skutki uboczne (tzw. błąd przesilenia) niszczące środowisko przyrodnicze i etniczno-kulturowe, tworzące „skansen kulturowy” (SYNAK 2000).

$\mathrm{W}$ aspekcie pozytywnym turystyka, kreując zainteresowanie elementami kultury lokalnych społeczności, spełnia jednak ważną funkcję w uchronieniu jej przed całkowitym zapomnieniem. Napływ turystów stwarza popyt na regionalne pamiątki czy kuchnię. $W$ miejscach, gdzie do tej pory kultura lu- 
dowa tkwiła w zapomnieniu, wykorzystuje się jej elementy w promocji regionu. Turystyka, oprócz szansy na rozwój gospodarczy obszarów wiejskich dotkniętych problemami strukturalnymi, jest więc także postrzegana jako możliwość zachowania elementów tradycji, które bez zainteresowania z zewnątrz uległyby zapomnieniu (PRZYBYŚ 2008). Fundamentalne znaczenie dla omawianego zjawiska mają dotacje pozyskiwane z Unii Europejskiej, dzięki którym lokalne tradycje podlegają rewitalizacji. Turystyka jest szansą odbudowania tradycji ludowych, co ma szczególne znaczenie w regionach, gdzie nie ma innych alternatyw rozwoju niż turystyka (ISAŃSKI 2008). Jest to zatem swego rodzaju paradoks - z jednej strony turystyka pomaga rozwijać się mniej zamożnym regionom, z drugiej niszczy autentyczność kultury ich mieszkańców.

\section{Proces komercjalizacji kultury ludowej pod wpływem turystyki}

Komercjalizacja zasobów kultury ludowej pod wpływem turystyki jest wieloetapowym procesem (rys. 1). Na początkowym etapie zasoby kultury ludowej funkcjonują jako relikty kultury dawnej (pierwotnej) bądź kultura ludowa uwspółcześniona. Początkiem ich komercjalizacji jest pojawienie się turysty, który zauważa i dokonuje oceny zasobów kulturowych. Następnie ma miejsce wybór zasobów i ich przygotowanie na potrzeby turystyki (etap walorów turystycznych), kiedy pojawia się podstawowe zagospodarowanie turystyczne (m.in. tablice informacyjne). Etap atrakcji turystycznych oznacza faktyczne zainteresowanie turystów walorami kulturowymi oraz związany z nim dalszy rozwój infrastruktury turystycznej (m.in.: muzeum, sklep z pamiątkami itp.). Ostatni, IV etap, to tworzenie się produktu turystycznego (pojawienie się elementów rynkowych takich, jak np. cena czy działania promocyjne). Turysta ma możliwość wyboru atrakcji spośród szerokiej oferty: zwiedzanie miejsca z przewodnikiem, udział w warsztatach, pokazach folklorystycznych.

Kultura ludowa w postaci produktu turystycznego staje się kulturą skomercjalizowaną, jednak może mieć zarówno charakter autentyczny, jak i nieautentyczny. Kultura ludowa skomercjalizowana autentyczna rozumiana jest jako ta, w której mimo głównego celu jej funkcjonowania, jakim jest turystyka, zachowuje autentyczność form i nawiązuje do przekazu tradycyjnego. 
Z kolei kultura ludowa skomercjalizowana nieautentyczna to taka, w której wartości ulegają zmianie i uproszczeniu na potrzeby ruchu turystycznego.

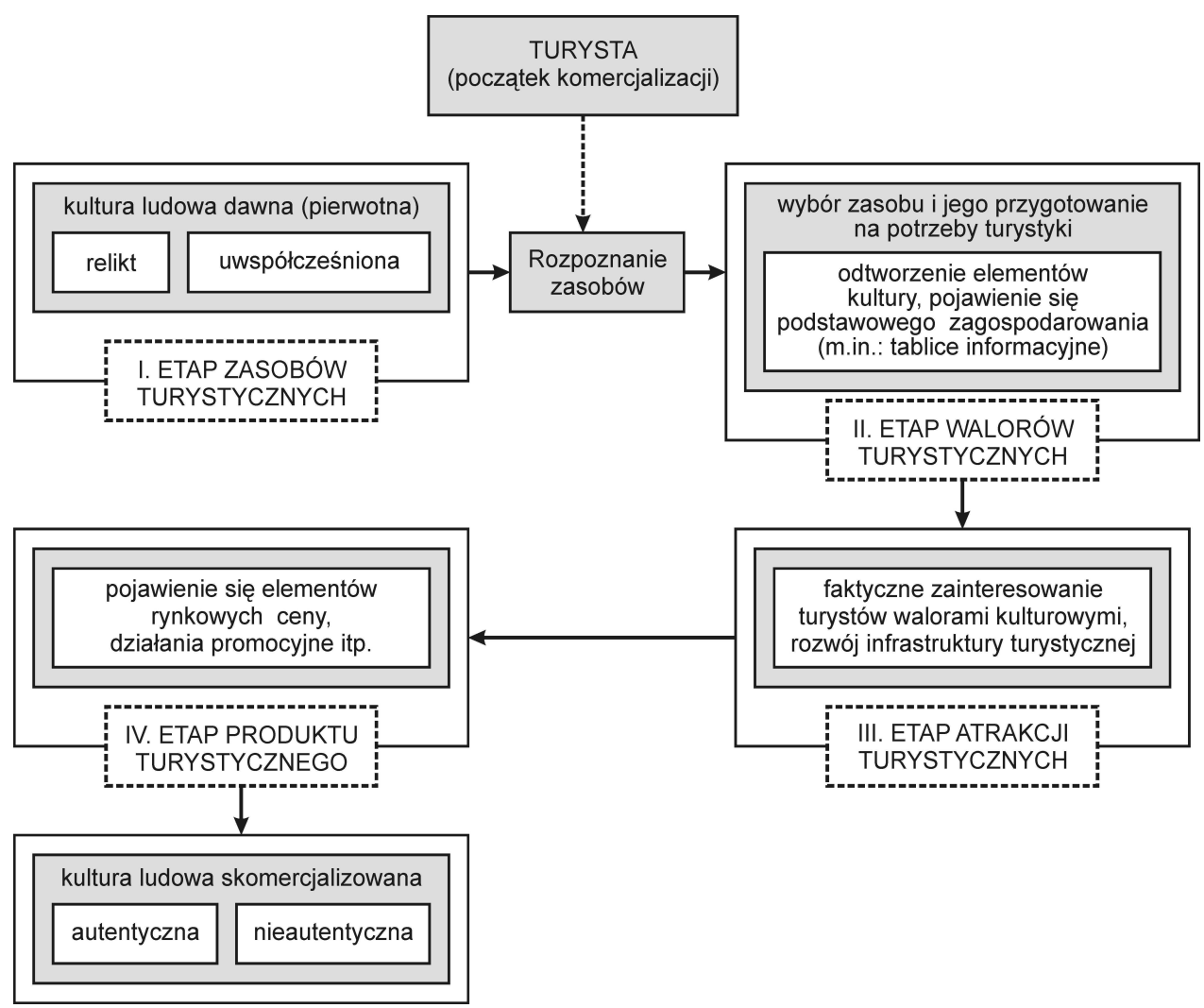

Rys. 1. Proces komercjalizacji zasobów kultury ludowej pod wpływem turystyki Źródło: opracowanie własne na podstawie A. KOWALCZYK (2009)

\section{Uniwersalny model badań komercjalizacji kultury ludowej pod wpływem turystyki}

Zaproponowany przez autorkę model badawczy składa się z dwóch etapów i ma charakter uniwersalny. Pierwszym etapem jest określenie roli determinant warunkujących proces komercjalizacji, drugim - ocena komercjalizacji za pomocą odpowiednio skonstruowanych mierników. 
Najważniejszymi determinantami procesu komercjalizacji kultury ludowej pod wpływem turystyki są: zasobność środowiska przyrodniczego, postęp cywilizacyjny, uwarunkowania historyczne, działalność instytucji branżowych, tradycje wykorzystania zasobów kultury ludowej w turystyce oraz intensywność ruchu turystycznego. W wielu miejscach na proces komercjalizacji kultury ludowej pod wpływem turystyki najsilniej wpływają tylko niektóre determinanty, co zmniejsza rolę pozostałych.

Zaproponowane determinanty określają hipotetyczną komercjalizację kultury ludowej w wybranym regionie, którą następnie odniesiono do właściwej komercjalizacji analizowanej na trzech płaszczyznach: produktów turystycznych, zachowań turystów i twórczości ludowej. Trzy spośród wymienionych determinant mają charakter mierzalny - postęp cywilizacyjny, działalność instytucji branżowych oraz intensywność ruchu turystycznego (MOKRAS-GRABOWSKA 2010). W celu określenia ich znaczenia dla badanego zjawiska posłużono się odpowiednio skonstruowanymi miernikami:

2) postęp cywilizacyjny: liczba podmiotów gospodarki narodowej REGON według PKD (bez sekcji A i B²) (urbanizacja ekonomiczna), drogi publiczne o twardej nawierzchni/1 $\mathrm{km}^{2}$ (urbanizacja przestrzenna), odsetek mieszkańców z wykształceniem wyższym (urbanizacja demograficzna). W celu umożliwienia porównania wszystkie mierniki odniesiono do średniej krajowej $=1$, a następnie obliczono $\mathrm{z}$ nich średnią arytmetyczną, co umożliwiło uzyskanie jednego miernika określonego w pracy jako średni postęp cywilizacyjny. W przypadku gdy miernik przyjmuje wartość $\mathrm{w}$ przedziale $<0 ; 1>$, został określany jako „mały”, natomiast w przedziale $<1 ; \infty)$ jako "duży”.

3) działalność instytucji branżowych: powierzchnia $\left(\mathrm{w} \mathrm{km}^{2}\right)$ przypadająca na jedną spółdzielnię Cepelii (niezależnie od jej funkcjonowania w okresie prowadzenia badań). Miernik odniesiono następnie do średniej krajowej $=1$. Otrzymane $\mathrm{w}$ poszczególnych regionach wartości miernika mieszczą się w przedziałach: < 0; $1>$ (nieaktywna/mało aktywna) i $<1 ; \infty$ ) (aktywna).

4) intensywność ruchu turystycznego: wskaźnik Charvata (liczba osobonoclegów/100 mieszkańców stałych). Miernik ten, podobnie jak dwa poprzednie, odniesiono do średniej krajowej $=1$. Otrzymane wartości mieszczą się w przedziałach: $<0 ; 1>$ (mały) i $<1 ; \infty)$ (duży).

2 Od wszystkich podmiotów zarejestrowanych w rejestrze REGON (PKD 2007 r.) odjęto sekcje A i B, aby uzyskać liczbę podmiotów gospodarczych wszystkich pozostałych sekcji. 
Rolę determinant niemierzalnych (zasobność środowiska przyrodniczego, uwarunkowania historyczne, tradycje wykorzystania zasobów kultury ludowej w turystyce) omówiono w sposób opisowy.

Kolejnym etapem jest ocena stopnia komercjalizacji kultury ludowej pod wpływem turystyki. Analizy dokonano w oparciu o przeprowadzone badania ankietowe oraz zgromadzone $\mathrm{w}$ terenie dane. Oceny uproduktowienia kultury ludowej (płaszczyzna I - produktów turystycznych) dokonano poprzez analizę i porównanie wszystkich zarejestrowanych w poszczególnych regionach produktów turystycznych tworzonych na bazie zasobów kultury ludowej. W przypadku karczm regionalnych informacji dostarczyła analiza stopnia komercjalizacji tradycji kulinarnych, w której porównano ofertę losowo wybranych karczm. W badanych karczmach porównano ponadto odsetek potraw regionalnych $\mathrm{w}$ ogólnej liczbie potraw serwowanych w lokalach oraz występowanie elementów uznanych za "ludowe". W celu zobrazowania zjawiska uproduktowienia kultury ludowej pod wpływem turystyki zastosowano także miernik komercjalizacji wydarzeń folklorystycznych $(M k w f)$ :

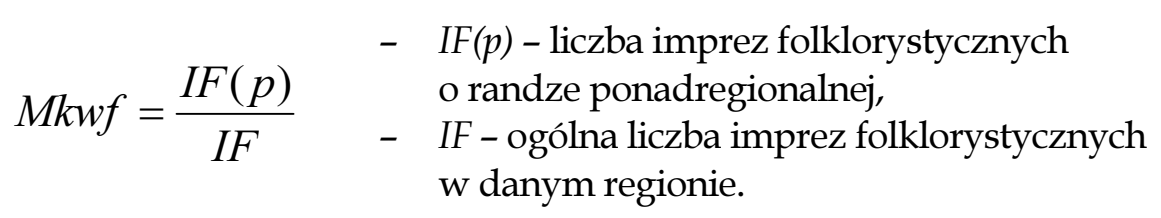

„Konsumpcję” kultury ludowej przez turystów (płaszczyzna II - zachowania turystów) określono poprzez charakterystykę ruchu turystycznego regionów i analizę najbardziej komercyjnych zachowań turystów (na podstawie przeprowadzonych $z$ turystami kwestionariuszy wywiadu). Na tej płaszczyźnie zastosowano miernik „konsumpcji” kultury ludowej przez turystów $(\operatorname{Mkkl}(t))$ :

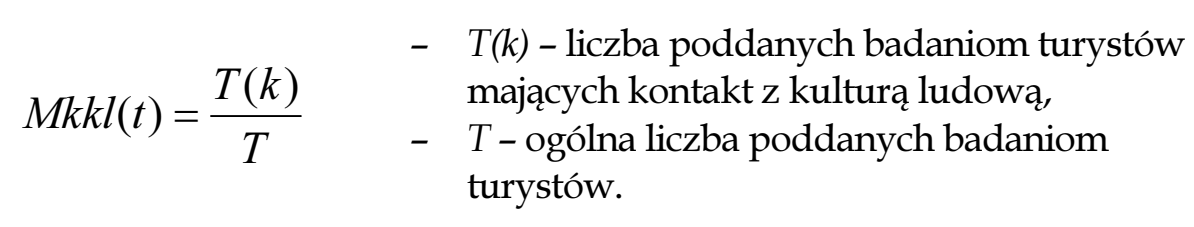

W przypadku twórczości ludowej (płaszczyzna III - twórczość ludowa) analizie poddano działalność twórców ludowych i pozostałych mieszkańców zajmujących się twórczością ludową, niefigurujących w spisach twór- 
ców Stowarzyszenia Twórców Ludowych. Dokonano również analizy najbardziej komercyjnych ich zachowań oraz zastosowano miernik komercjalizacji twórczości ludowej $(M k t l)$ :

$$
\begin{aligned}
& \text { - } \quad T L+M(t) \text { - liczba poddanych badaniom twór- } \\
& M k t l=\frac{T L+M(t)}{T L+M}-\begin{array}{l}
\text { twórcy ludowego tworzących na sprzedaż dla } \\
\text { turystów, }
\end{array}
\end{aligned}
$$

W celu określenia ogólnego stopnia komercjalizacji kultury ludowej pod wpływem turystyki w każdym z badanych regionów obliczono średnią arytmetyczną ze wszystkich mierników cząstkowych. Dzięki temu otrzymano syntetyczny miernik komercjalizacji (Smk), obliczony według wzoru:

$$
\begin{array}{cl}
S m k=\frac{M k w f+M k k l(t)+M k t l}{3}- & M k w f-\text { miernik komercjalizacji } \\
& \text { wydarzeń folklorystycznych, } \\
3 & M k k l(t)-\text { miernik konsumpcji kul- } \\
& \text { tury ludowej przez turystów, } \\
- & M k t l-\text { miernik komercjalizacji } \\
& \text { twórczości ludowej }
\end{array}
$$

$\mathrm{Na}$ podstawie syntetycznego miernika komercjalizacji hipotetycznie określono również rolę turystyki w zachowaniu zasobów kultury ludowej. Wszystkie mierniki komercjalizacji przyjmują wartości w przedziale $<0 ; 1>$. Im wyższa wartość miernika, tym większy stopień komercjalizacji danego zjawiska. Wartości miernika zawierają się $\mathrm{w}$ następujących przedziałach ${ }^{3}$ : 0,00-0,20 (bardzo mały), 0,21-0,40 (mały), 0,41-0,60 (średni), 0,61-0,80 (duży), 0,81-1,00 (bardzo duży).

${ }^{3}$ Skala Likerta. 


\section{Wyniki badań}

Badania komercjalizacji kultury ludowej pod wpływem turystyki przeprowadzono w okresie trzech lat (2003-2005) w trzech regionach, zamieszkiwanych przez odmienne grupy etnograficzne4: region włodawski (Grupa Kresowa okolic Włodawy, gminy: Włodawa, Hanna, Wyryki, Wola Uhruska, Hańsk), region podhalański (Górale Podhalańscy, gminy: Zakopane, Poronin, Kościelisko, Bukowina Tatrzańska, Biały Dunajec) oraz region kartuski (Kaszubi okolic Kartuz, gminy: Kartuzy, Chmielno, Somonino, Sulęczyno, Stężyca). Każdy z regionów domknięto granicami administracyjnymi gmin badaniom poddano po pięć gmin $\mathrm{w}$ każdym $\mathrm{z}$ regionów ( $\mathrm{w}$ przypadku regionu podhalańskiego stanowią one cały powiat tatrzański).

Główną metodą pracy były badania ankietowe opierające się na narzędziu, jakim jest kwestionariusz wywiadu. W każdym z trzech obszarów badań analizie poddano jednakową liczbę kwestionariuszy wywiadu przeprowadzonych z mieszkańcami (200 sztuk) i z turystami (100 sztuk). Liczba kwestionariuszy wywiadu przeprowadzonych wśród twórców ludowych jest różna w każdym regionie, co jest podyktowane liczebnością badanej populacji.

Kwestionariusz wywiadu dla twórców ludowych zawierał głównie pytania dotyczące ich twórczości - dziedzin, celów, form, korzyści, przeznaczenia, sposobu nabycia danych umiejętności, kontaktu z turystami, a także świadomości regionalnej. Podobnie było z kwestionariuszem dla mieszkańców regionu - oprócz pytań dotyczących możliwości rozwoju turystyki w oparciu o lokalną kulturę ludową, znaczące było pytanie o posiadane umiejętności z zakresu twórczości ludowej i ewentualne wykorzystywanie ich w praktyce, a następnie część dotycząca stosunku do tej twórczości. W przypadku kwestionariusza dla turystów pytania dotyczyły głównie wiedzy na temat lokalnej kultury ludowej, form kontaktu z zasobami tej kultury, a także potencjalnych zainteresowań turystów w badanej dziedzinie. Taki dobór pytań pozwolił autorce ocenić stopień komercjalizacji kultury ludowej pod wpływem turystyki w wybranych regionach.

Jak wynika z tab. 1, region włodawski ma najmniej sprzyjające warunki do potencjalnej komercjalizacji kultury ludowej pod wpływem turystyki, na co wskazują wszystkie analizowane determinanty.

${ }^{4}$ Dobór regionów miał charakter subiektywny i został oparty na wieloletnich obserwacjach grup etnograficznych w Polsce. 
Trudno dostępne obszary podmokłe powodują dużą zasobność środowiska przyrodniczego. Przeciętny postęp cywilizacyjny jest najniższy ze wszystkich trzech badanych regionów (w tym najniższa urbanizacja przestrzenna i dostępność komunikacyjna), a działalność instytucji branżowych jest nieaktywna. Bardzo istotne znaczenie dla badanego zjawiska ma także częściowo przerwana ciągłość kulturowa regionu, przy jednoczesnym braku działań mających na celu zasklepienie lokalnej kultury (niekorzystne uwarunkowania historyczne: liczne konflikty zbrojne na przestrzeni wieków, różna przynależność państwowa, powojenne przesiedlenia i ponowne akcje osadnicze). Część ludności autochtonicznej opuściła region, a pozostali jego mieszkańcy $\mathrm{w}$ naturalny sposób nadal kultywują dawne tradycje, jednak w wyniku ogólnego zaniedbania regionu nie czują z nim silnego związku, a co za tym idzie nie dbają o lokalne dziedzictwo i nie upatrują $\mathrm{w}$ nim potencjalnej atrakcji turystycznej. Autentyczny potencjał kulturowy regionu stopniowo zanika, a nieliczne produkty turystyczne go wykorzystujące odnoszą się tylko do niektórych jego elementów.

Tabela 1. Znaczenie poszczególnych determinant warunkujących proces komercjalizacji na obszarach badań

\begin{tabular}{|l|c|c|c|}
\hline \multirow{2}{*}{ Determinanta } & \multicolumn{3}{c|}{ Obszar badań - region } \\
\cline { 2 - 4 } & włodawski & podhalański & kartuski \\
\hline Zasobność środowiska przyrodniczego & duża & duża & duża \\
\hline Przeciętny postęp cywilizacyjny & 0,68 (mały) & 1,06 (duży) & 0,74 (mały) \\
\hline Uwarunkowania historyczne & niekorzystne & korzystne & $\begin{array}{c}\text { czéściowo } \\
\text { niekorzystne }\end{array}$ \\
\hline Działalność instytucji branżowych & $\begin{array}{c}0,00 \\
\text { (nieaktywna) }\end{array}$ & $\begin{array}{c}4,42 \\
\text { (aktywna) }\end{array}$ & $\begin{array}{c}3,00 \\
\text { (aktywna) }\end{array}$ \\
\hline $\begin{array}{l}\text { Tradycje wykorzystania zasobów } \\
\text { kultury ludowej w turystyce }\end{array}$ & małe & duże & małe \\
\hline Intensywność ruchu turystycznego & 3,5 (duża) & 18,14 (duża) & 1,35 (duża) \\
\hline
\end{tabular}

Źródło: opracowanie własne na podstawie badań terenowych

Małe są również tradycje wykorzystania zasobów kultury ludowej w turystyce (dominuje turystyka wypoczynkowa rozwijana dopiero w okresie po II wojnie światowej). Z kolei duża intensywność ruchu turystycznego regionu włodawskiego (większa niż w regionie kartuskim) nie przyczynia się do uproduktowienia lokalnej kultury, głównie ze względu na fakt, że turystyka koncentruje się tu przede wszystkim w rejonie jeziora Białego w Oku- 
nince i ma charakter typowo wypoczynkowy - walory z zakresu kultury ludowej nie mają tu dużego znaczenia.

Całkowicie odmiennie prezentuje się pod względem badanego zjawiska region podhalański, w którym wszystkie determinanty wskazują na wysoką komercjalizację. Wszystkie czynniki mają tu istotne znaczenie, jedynie duża zasobność środowiska przyrodniczego nie odgrywa podstawowej roli, głównie ze względu na odległe tradycje popularyzacji regionu i związaną z tym jego dużą dostępność. Największy z trzech badanych regionów charakteryzuje przeciętny postęp cywilizacyjny, głównie poprzez nowe inicjatywy turystyczne, przyczynia się do znacznego popularyzowania zasobów kulturowych regionu. Najbardziej aktywna działalność instytucji branżowych i największa spośród badanych regionów intensywność ruchu turystycznego powodują wykorzystanie coraz większej liczby elementów kultury ludowej w turystyce i tworzenie kolejnych produktów turystycznych.

Największe znaczenie $\mathrm{w}$ regionie mają jednak dwie determinanty: korzystne uwarunkowania historyczne oraz tradycje wykorzystania zasobów kultury ludowej w turystyce. Proces popularyzacji regionu rozpoczął się tu bowiem już w połowie XIX w., wcześnie zwrócono także uwagę na piękno podhalańskiej przyrody i kultury. W ten sposób w mieszkańcach Podhala wykształciło się silne poczucie odrębności regionalnej i dbałość o lokalną kulturę (KROH 2003). Efektem tych działań jest obecnie duża chęć górali do prezentowania swojej kultury „na zewnątrz”, co wpływa na jej komercjalizację pod wpływem turystyki. Z drugiej strony jednak, mieszkańcy regionu podhalańskiego czują silne przywiązanie do swojej kultury i nadal kultywują wiele jej elementów bez udziału turystyki.

Region kartuski charakteryzuje najbardziej złożona sytuacja. Określony w pracy jako "mały” przeciętny postęp cywilizacyjny jest wyższy niż w przypadku regionu włodawskiego i już od czasów II wojny światowej przyczynia się do zaniku materialnych elementów kultury ludowej (gwałtowna urbanizacja regionu w okresie powojennym). Dzięki temu zmniejsza się także zasobność środowiska przyrodniczego, która mimo że jest określona jako duża, nie odgrywa podstawowej roli w badanym zjawisku. Duchowe elementy funkcjonują w lokalnej kulturze dzięki silnej identyfikacji mieszkańców z regionem. Ma to uzasadnienie w uwarunkowaniach historycznych określonych w pracy jako częściowo niekorzystne. Silna germanizacja oraz próby zniszczenia odrębności regionalnej Kaszubów pod zaborem pruskim, przyczyniły się do zasklepienia kultury ludowej - od połowy XIX w. zaznaczyła się tu aktywność lokalnych działaczy społecznych, pasjo- 
natów, artystów i badaczy (F. Ceynowa, T. i I. Gulgowscy, A. i F. Majkowscy). W wyniku tej działalności zachowaniu lub odtworzeniu uległo wiele elementów kaszubskiej kultury. Region ten był także dotknięty przesiedleniami, co spowodowało częściowo przerwaną ciągłość kulturową. Z kolei działania władz Polski Ludowej doprowadziły do znacznej "skansenizacji” wielu elementów kaszubskiej kultury i wykreowania z nich jedynie atrakcji turystycznych (popularyzacja tzw. masowego folkloru kaszubskiego). Przemawia za tym również „aktywna” działalność instytucji branżowych. Ogółem na Kaszubach miało zatem miejsce częściowe zachwianie i tzw. uśmiercenie tradycyjnej formacji kulturowej, nawet tam gdzie większość stanowili autochtoni. Kaszubi to jednak społeczność, która w niesprzyjających warunkach do dziś zachowała swoje tradycje.

Analiza poszczególnych determinant dostarczyła autorce cennych wniosków dotyczących hipotetycznej komercjalizacji kultury ludowej pod wpływem turystyki w badanych regionach. Wynika z niej, że najwyższą komercjalizacją odznacza się prawdopodobnie region podhalański, a najniższą region włodawski. Fakt ten został potwierdzony w wyniku przeprowadzenia analizy komercjalizacji zasobów kultury ludowej na wspomnianych trzech płaszczyznach.

Tabela 2. Wartości mierników stopnia komercjalizacji kultury ludowej pod wpływem turystyki w obszarach badań

\begin{tabular}{|l|c|c|c|c|}
\hline \multirow{2}{*}{$\begin{array}{l}\text { Obszar } \\
\text { badań }\end{array}$} & $\begin{array}{c}\text { komercjalizacji wy- } \\
\text { darzeń folklorys- } \\
\text { tycznych } \\
\text { (Mkwf) }\end{array}$ & $\begin{array}{c}\text { "konsumpcji" } \\
\text { kultury ludowej } \\
\text { przez turystów } \\
\text { Mkkl (t) }\end{array}$ & $\begin{array}{c}\text { komercjalizacji } \\
\text { twórczości ludo- } \\
\text { wej } \\
\text { Mktl }\end{array}$ & $\begin{array}{c}\text { syntetyczny } \\
\text { miernik } \\
\text { komercjalizacji } \\
\text { (Smk) }\end{array}$ \\
\hline $\begin{array}{l}\text { Region } \\
\text { włodawski }\end{array}$ & $\begin{array}{c}0,13 \\
\text { (bardzo mały) }\end{array}$ & $\begin{array}{c}0,85 \\
\text { (bardzo duży) }\end{array}$ & $\begin{array}{c}0,19 \\
\text { (bardzo mały) }\end{array}$ & $\begin{array}{c}0,39 \\
\text { (mały) }\end{array}$ \\
\hline $\begin{array}{l}\text { Region } \\
\text { podhalański }\end{array}$ & 0,32 & 0,98 & 0,42 & 0,57 \\
(mały) & (bardzo duży) & (średni) & (średni) \\
\hline $\begin{array}{l}\text { Region } \\
\text { kartuski }\end{array}$ & $\begin{array}{c}0,15 \\
\text { (bardzo mały) }\end{array}$ & $\begin{array}{c}0,92 \\
\text { (bardzo duży) }\end{array}$ & $\begin{array}{c}0,45 \\
\text { (średni) }\end{array}$ & $\begin{array}{c}0,50 \\
\text { (średni) }\end{array}$ \\
\hline
\end{tabular}

Źródło: opracowanie własne na podstawie badań terenowych.

Jak wynika z tab. 2, wszystkie mierniki komercjalizacji kultury ludowej uzyskały najniższe wartości właśnie w regionie włodawskim. Ogólna komercjalizacja kultury ludowej pod wpływem turystyki określona na podstawie syntetycznego miernika komercjalizacji jest mała $(0,39)$. Region włodaw- 
ski spośród trzech badanych regionów jest zatem tym, który posiada najwięcej zasobów kultury ludowej niewykorzystywanej w turystyce, zachowanej w sposób naturalny.

Uproduktowienie kultury ludowej jest tu najmniejsze ze wszystkich badanych regionów - nie zarejestrowano tu szlaków turystycznych o tematyce etnograficznej oraz karczm regionalnych, występuje tylko jedno muzeum o tematyce etnograficznej (Muzeum Pojezierza Łęczyńsko-Włodawskiego ekspozycja etnograficzna). Ponadto, odbywa się tu najmniej ze wszystkich badanych regionów imprez folklorystycznych (29).

„Konsumpcja” kultury ludowej przez turystów (zestawienie najbardziej komercyjnych zachowań turystów) jest również najmniejsza ze wszystkich trzech badanych regionów (rys. 2).

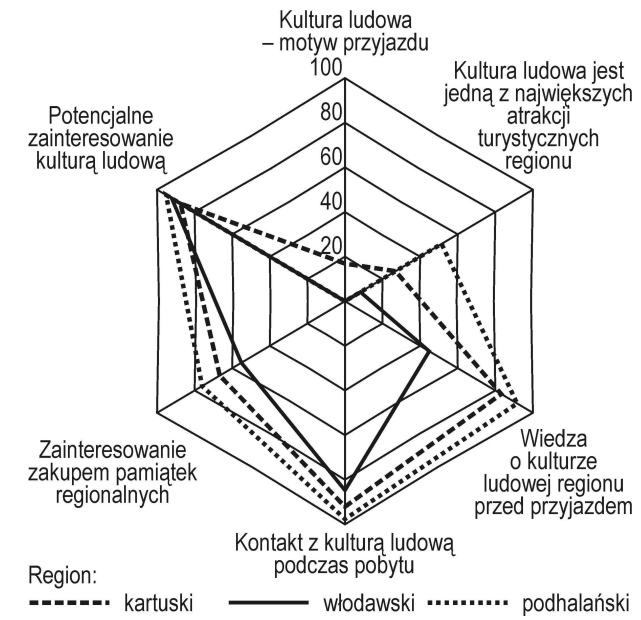

Rys. 2. „Konsumpcja” kultury ludowej przez turystów obszarów badań - zestawienie cech komercyjnych (w procentach)

Źródło: opracowanie własne na podstawie badań terenowych

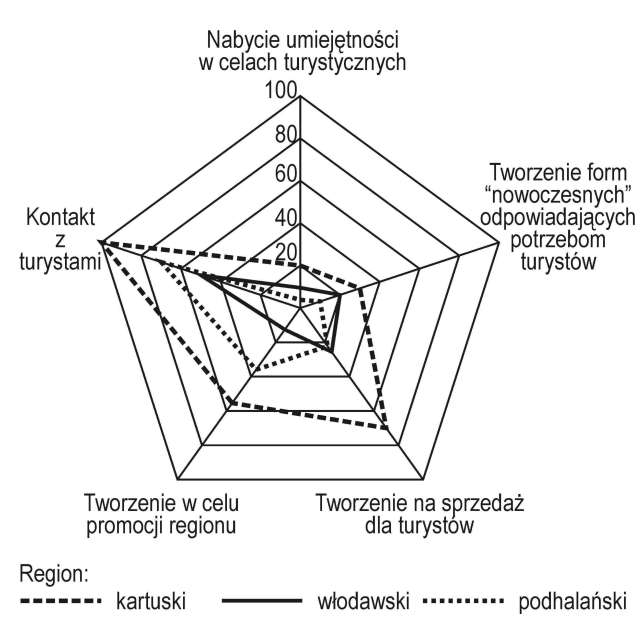

Rys. 3. Komercjalizacja twórczości ludowej twórców ludowych - zestawienie cech komercyjnych(w procentach) Źródło: opracowanie własne na podstawie badań terenowych

Podobnie jest w przypadku zestawienia najbardziej komercyjnych zachowań twórców ludowych (rys. 3) i pozostałych mieszkańców zajmujących się twórczością, niefigurujących w wykazach twórców ludowych (rys. 4).

W regionie podhalańskim zastosowane mierniki komercjalizacji uzyskały różne wartości, z czego dwa (miernik komercjalizacji wydarzeń folklory- 
stycznych i „konsumpcji” kultury ludowej przez turystów) - najwyższe spośród trzech badanych regionów. Również zestawienie najbardziej komercyjnych zachowań turystów dowodzi najwyższej komercjalizacji regionu (rys. 2). Z kolei komercjalizacja twórczości ludowej jest niższa niż w regionie kartuskim, co może sugerować silne przywiązanie mieszkańców do swojej tradycji i tworzenie nie tylko na potrzeby turystyczne (rys. 3, 4). Mimo to ogólna komercjalizacja kultury ludowej pod wpływem turystyki obliczona za pomocą syntetycznego miernika komercjalizacji jest tu największa $(0,57)$, chociaż uplasowała się w przedziale „średnia”. Ciekawych spostrzeżeń dostarczyła także analiza stopnia komercjalizacji tradycji kulinarnych zarówno wykorzystanie elementów ludowych w karczmach regionalnych, jak i odsetek potraw regionalnych w ogólnej liczbie potraw są na Podhalu zdecydowanie wyższe niż w regionie kartuskim.

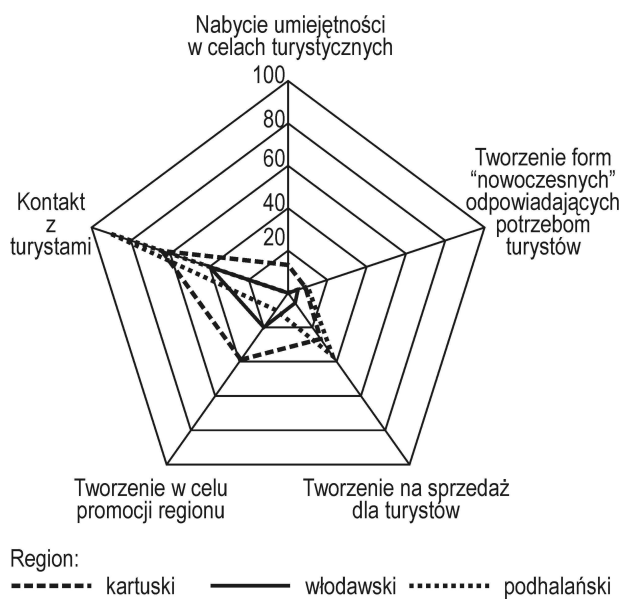
Rys. 4. Komercjalizacja twórczości ludowej mieszkańców niefigurujących w spisach twórców ludowych - zestawienie cech komercyjnych (w procentach)
Źródło: opracowanie własne na podstawie badań terenowych

Najwyższa spośród trzech badanych regionów komercjalizacja na płaszczyźnie twórczości ludowej ma miejsce w regionie kartuskim - wypromowani w okresie powojennym przez Cepelię twórcy mają wyraźnie sprecyzowany cel swojej działalności, jakim jest turystyka. Wiele zachowań osób zaj- 
mujących się twórczością ludową wykazuje więc tendencje komercyjne (rys. $3,4)$. Nie bez znaczenia dla komercjalizacji kaszubskiej kultury jest tzw. renesans etniczności, mający miejsce w ostatnim dwudziestoleciu. Ruch ten, mający na celu „odnowienie” zjawisk kulturowych, przyczynia się jednocześnie do coraz większej ich komercjalizacji. Region kartuski uplasował się pod względem badanego zjawiska na środkowej pozycji - jego ogólna komercjalizacja jest wyższa niż $\mathrm{w}$ regionie włodawskim, a niższa niż $\mathrm{w}$ regionie podhalańskim $(0,50)$.

\section{Podsumowanie}

Obserwowany $\mathrm{w}$ ostatnich latach dynamiczny rozwój turystyki w Polsce przyczynia się do coraz większego wykorzystania oraz uproduktowienia zasobów kultury ludowej. Dziedzictwo kulturowe regionów jest bowiem coraz bardziej dostrzeganym elementem wizerunku regionów. Występy zespołów folklorystycznych czy prezentacje rękodzieła twórców ludowych (w tym potraw regionalnych) urozmaicaja imprezy turystyczne o bardzo różnorodnym charakterze (kulturowe, sportowe czy rekreacyjne). Powstaje pytanie, czy prezentowane odwiedzającym walory mimo swej komercyjnej formy mają charakter autentyczny. Turystyka jest bowiem czynnikiem, który wpływa na komercjalizację kultury ludowej przyczyniając się do jej uproduktowienia, będąc tym samym jednym $z$ największych zagrożeń autentyczności miejsca. Ma jednak także znaczenie w zachowaniu zasobów kultury ludowej, przyczyniając się do ich przetrwania w znacznie większym stopniu, co potwierdzają zaprezentowane $\mathrm{w}$ artykule przykłady.

$\mathrm{Z}$ przeprowadzonych $\mathrm{w}$ pracy analiz wynikają ponadto następujące prawidłowości:

- kultura ludowa w Polsce przeszła od końca XVIII w. wiele przemian zmianie uległy jej podstawowe funkcje, takie jak funkcja użytkowa, religijna, kultowa czy identyfikacyjna. Zasoby kultury ludowej stawały się na przestrzeni wieków artystyczną inspiracją, elementem estetycznym i dekoracyjnym, poznawczym czy w końcu atrakcją turystyczną;

- kultura ludowa dawna i jej relikty zachowały się w Polsce jedynie $\mathrm{w}$ niewielkim stopniu - głównie na obszarach o niskim postępie cywilizacyjnym, z dala od większych wpływów miejskich, a także na 
terenach silnie izolowanych przez środowisko przyrodnicze, czego przykładem jest region włodawski;

- w wielu regionach Polski funkcjonuje tzw. kultura ludowa dawna uwspółcześniona, oznaczająca zachowanie elementów kultury, przy jednoczesnym uwspółcześnieniu ich $\mathrm{w}$ wyniku nowo powstałych potrzeb cywilizacyjnych. $Z$ takim rodzajem kultury ludowej spotkano się podczas badań we wszystkich trzech regionach;

- okres po II wojnie światowej (do roku 1989) przyczynił się do zachowania w celach komercyjnych tylko wybranych (materialnych) elementów kultury ludowej, w wyniku czego jej elementy duchowe (w tym związane $\mathrm{z}$ religią) zanikły bądź przetrwały jedynie fragmentarycznie. Znaczący wkład $\mathrm{w}$ komercjalizację kultury ludowej $\mathrm{w}$ Polsce miała działalność Centrali Przemysłu Ludowego i Artystycznego (Cepelia), która mimo że przyczyniła się do zachowania w sposób wybiórczy wielu jej elementów, spowodowała także silne ich umasowienie - nastawienie na miejskiego odbiorcę. Przykładem takich działań jest zarówno region podhalański, jak i kartuski;

- ponowny rozkwit kultury ludowej obserwowany jest $\mathrm{w}$ Polsce od 1989 r., kiedy szansą dla zaniedbanych społecznie i gospodarczo obszarów wiejskich stała się m.in. turystyka, w tym te jej formy, które wykorzystują zasoby kultury ludowej. Zaczęło także powstawać coraz więcej produktów turystycznych (nie zawsze autentycznych), opartych na zasobach kultury ludowej. Znaczącą rolę w ponownym rozwoju kultury ludowej odgrywają także środki finansowe uzyskiwane po $2004 \mathrm{r}$. z programów unijnych.

\section{BIBLIOGRAFIA}

ĆWIKLIŃSKA J., 2009, Turystyka i kultura - od komercjalizacji do dialogu kultur, [w:] Kultura i turystyka - razem, ale jak?, materiały pokonferencyjne, A. Stasiak (red.), Wyd. WSTH w Łodzi, Łódź, s. 7-21.

GEISE P., 2008, Karnawał i karnawalizacja w kontekście turystyki miejskiej. Wybrane zagadnienia, [w:] W kręgu humanistycznej refleksji nad turystyka kulturowa, M. Kazimierczak (red.), Wyd. AWF w Poznaniu, Poznań, s. 83-95.

ISAŃSKI J., 2008, Wpływ turystyki na środowisko społeczno-kulturowe. Skutki rozwoju turystyki w środowisku społecznym - szanse i zagrożenia, [w:] Uwarunkowania i plany rozwoju turystyki. Zasoby antropogeniczne. Krajobraz. Ruch turystyczny, Z. Młynarczyk (red.), A. Zajadacz (red.), t. II, Wyd. Uniwersytetu im. A. Mickiewicza w Poznaniu, Poznań, s. 27-40. 
KOWALCZYK A., 2008, Wspótczesna turystyka kulturowa - między tradycją a nowoczesnościa, [w:] Turystyka kulturowa. Spojrzenie geograficzne, "Geografia Turyzmu” 1, s. 9-57.

KrOH A., 2003, Tatry i Podhale, ser. „A to Polska właśnie”, Wyd. Dolnośląskie, Wrocław, ss. 280.

MADEJ T., 2008, Rola turystów z "unikatu” w odrodzeniu tradycji Niedzieli Palmowej we wsi Łyse na Kurpiach, [w:] W kręgu humanistycznej refleksji nad turystyka kulturowa, M. Kazimierczak (red.), Wyd. AWF w Poznaniu, Poznań, s. 243-240.

Mokras-GrabowsKa J., Rzeńca P., 2007, Województwo łódzkie. Przewodnik turystyczny, ROTWŁ, Łódź.

MOKRAS-GRABOWSKA J., 2010, Wptyw turystyki na komercjalizację kultury ludowej w Polsce, praca doktorska, Archiwum Uniwersytetu Łódzkiego

OlECHNICKI K., ZAŁĘCKI P., 1999, Słownik socjologiczny, Graffiti BC, Torun, ss. 262.

PRZECŁAWSKI K., 1996, Człowiek a turystyka. Zarys socjologii turystyki, Al-Bis, Kraków, ss. 160.

PRZYBYŚ J., 2008, Dylematy wiejskiej turystyki kulturowej, [w:] Turystyka kulturowa. Spojrzenie geograficzne, A. Kowalczyk (red.), Warszawa, s. 85-117.

STASIAK A., 2007, Szlaki turystyczne - zagospodarowanie, atrakcja czy produkt turystyczny?, [w:] Szlaki turystyczne a przestrzeń turystyczna. Materiały z konferencji, PTTK „Kraj”, Warszawa, s. $45-54$.

SYNAK B., 2000, Turystyka a środowisko kulturowo-etniczne. Szanse i zagrożenia, [w:] Polityka samorządu terytorialnego $w$ dziedzictwie turystycznym, zbiór materiałów pokonferencyjnych, M. Boruszczak (red.), Wyd. WSTiH w Sopocie, Gdańsk, s. 169-172.

Wielki słownik wyrazów obcych, 2003, PWN, Warszawa, ss. 1348.

WŁodARCZYK B., 2009, Przestrzeń turystyczna. Istota, koncepcje, determinanty rozwoju. Rozprawa habilitacyjna, Wyd. Uniwersytetu Łódzkiego, ss. 269.

ZARĘBA D., 2006, Ekoturystyka. Wyzwania i nadzieje, PWN, Warszawa, ss. 177. 